\title{
Magmatism at the onset of back-arc basin spreading in the Okinawa Trough
}

\author{
Chang-Hwa Chen ${ }^{a, *}$, Typhoon Lee ${ }^{\text {a.b }}$, Yuch-Ning Shieh ${ }^{c}$, Cheng-Hong Chen ${ }^{b}$, \\ Wen-Yu Hsu ${ }^{\text {a }}$ \\ anstitute of Earth Sciences, Academia Sinica, P.O. Box 1-55, Nankang, Taipei, Taiwan \\ ${ }^{\mathrm{b}}$ Institute of Geology, National Taiwan University, Taipei, Taiwan \\ 'Department of Earth and Atmospheric Sciences, Purdue University, West Lafayette, IN, USA
}

Received 25 August 1993; accepted 1 February 1995

\begin{abstract}
The Okinawa 'Trough is a back-arc basin behind the Ryukyu Arc in the western Pacific. Near its southwestern end is Kueishantao located, an volcanic islet offshore northeastern Taiwan. Kueishantao is the last volcanic center at the southernmost end of the Okinawa Trough's spreading axis. We report the isotopic ( $\mathrm{Nd}, \mathrm{Sr}, \mathrm{O}$ ) and chemical compositions of fresh andesites from Kueishantao. These rocks reveal extremely low Nd isotopic values $\left(\epsilon_{\mathrm{Nd}}=-1.9\right.$ to -5.2$)$, very high $\mathrm{Sr}$ ratios $\left({ }^{87} \mathrm{Sr} /{ }^{86} \mathrm{Sr}>0.705\right)$ and high $\delta^{18} \mathrm{O}$ (between 7 and 8). Such a strong continental signature on Kueishantao can be explained by crustal contamination, most likely the magma resulting from a MORB-type magma assimilation with about $30 \%$ local continental crust materials (CC) and/or the thick overlying sediments during the onset of the "rifting" stage of the active back-arc basin.

Basalts and dacites, which were dredged from the spreading axis in the central part of the Okinawa Trough (Iheya Deep and Aguni Deep, I\&A), exhibit high $\epsilon_{\mathrm{Nd}}$ values $(2.3-4.7)$ and low $\delta^{18} \mathrm{O}$ values $(<6.6)$ (Honma et al., 1991). This implies that less than $10 \%$ of continental crustal materials $(\mathrm{CC})$ were involved in the magma generation. Based on the trace-element ratios $(\mathrm{Nb} /$ $\mathrm{Zr}$ vs. $\mathrm{Ba} / \mathrm{Zr}$ ) of I\&A basaltic rocks, it suggests that the formation of I\&A magma needs not only two components (MORBtype magma and $\mathrm{CC}$ ) but also an island-arc basalt (IAB) component.

Since the spreading of the Okinawa Trough is believed to have propagated southwestwards in the last $2 \mathrm{Ma}$, we suggest that the magma from the southern tip segment (Kueishantao) may result from the onset of the "rifting" stage, while the magma from the central segment (I\&A region) may be generated in the more mature segment stepping in "drifting" stage in the backarc basin.
\end{abstract}

\section{Introduction}

Back-arc basins are semi-isolated basins lying behind the volcanic chain of the island-arc systems (Karig, 1971). The generally accepted theory of backarc basins is that they are formed through the extension spreading of oceanic crust similar to the processing of

\footnotetext{
* Corresponding author.
}

mid-ocean ridges and that they are basically an oceanic phenomenon, although some basins occur in active continental margins (Taylor and Karner, 1983; Wilson and Davidson, 1984; Wilson, 1989).

On the basis of trace-element geochemistry, backarc basin basalt exhibits both N-MORB-type and arctype characteristics (Taylor and Karner, 1983; Saunders and Tarney, 1984; Wilson, 1989). The isotopic variations of back-arc basins have been studied 

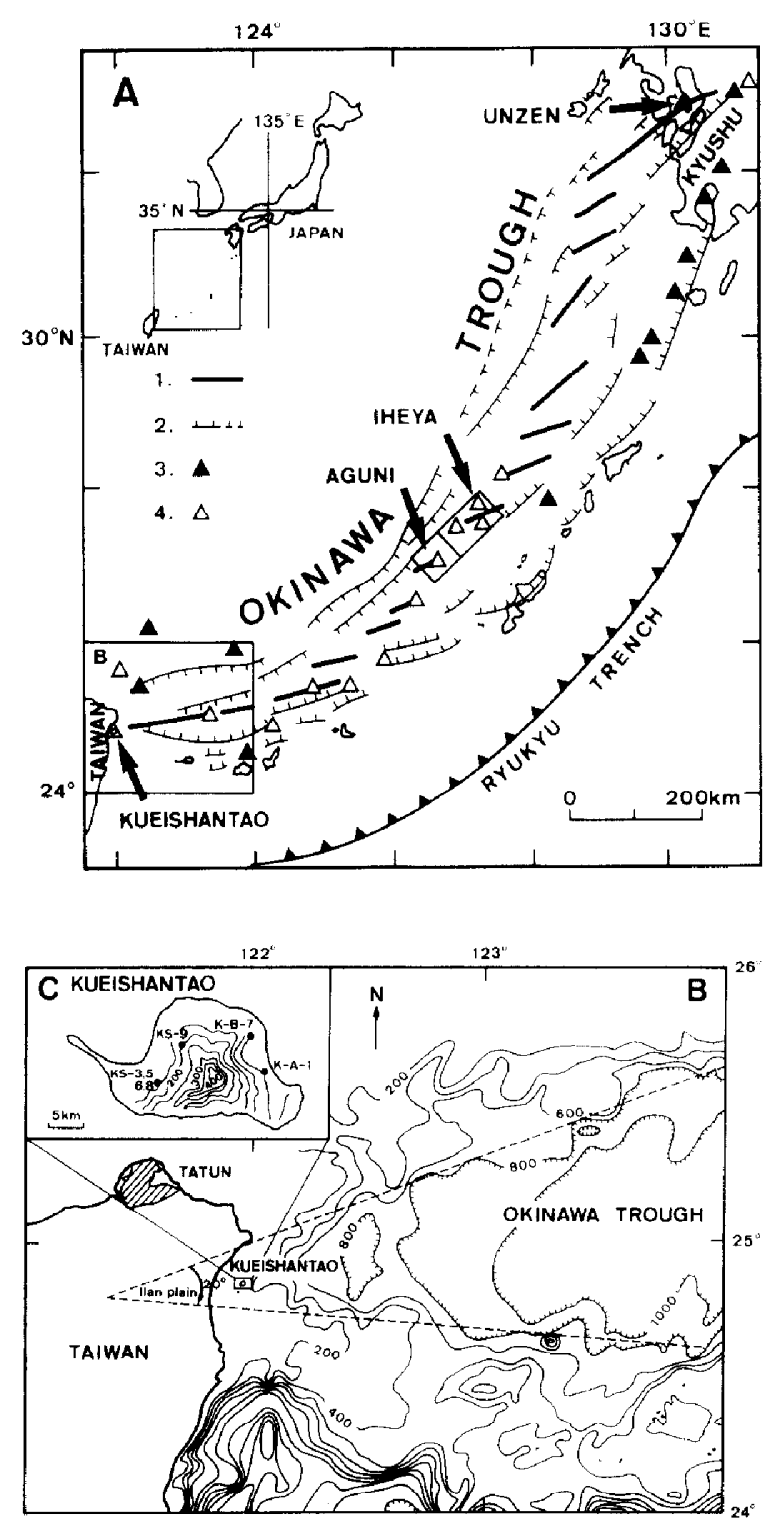

Fig. 1. ( $\Lambda$ ) The Okinawa Trough and its tectonic setting (after Kimura, 1985). The Okinawa Trough is behind the Ryukyu Arc on the Eurasian Continental margin. The Ryukyu Arc is the result of the subduction of the Philippine Sea Plate under the Eurasian Plate at the Ryukyu Trench. (B) The southern rim of the southwestern seg ment of the Okinawa Trough has been opened $20^{\circ}$ toward the south after 0.3 Ma (Lee and Liew, 1993); for location see inset in (A). The sample localities on Kueishantao are shown in insert (C). Legends: 1 . $=$ central rift $; 2=$ fault; $3 .=$ historically active volcanoes; 4. = active volcanoes.

in the Mariana Trough (Woodhead and Fraser, 1985; Volpe et al., 1987), the East Scotia Sea (Hawkesworth et al., 1977; Luff, 1982), the Japan Sea (Kaneoka,
1990; Cousens et al., 1994), the Lau basin (Jenner et al., 1987; Volpe et al., 1988; Auzende et al., 1990), the Fiji basin (Auzende et al., 1990) and the Bransfield Strait (Weaver et al., 1979). However, systematic studies of magma variations along the spreading axis during the onset of rifting stage are rare. The magma generation of an incipient back-arc spreading is still obscure. Here we investigate the magma at the tip of an actively opening trough which perhaps represents the characteristics of an initial rifting stage in a young back-arc basin.

The Okinawa Trough is a back-arc basin (Fig. 1 $\Lambda$ ) behind the Ryukyu Arc in the western Pacific, which is an elongated narrow graben with a maximum width of about $100 \mathrm{~km}$. The central segment began to rift at about 2 Ma (Kimura, 1985).

Bathymetry and seismic refraction studies of the southwestern Okinawa Trough and micro-seismicity surveys in the Ilan plain of northeastern Taiwan show that the western tip of the Okinawa Trough is extending past Kueishantao toward the Ilan plain (Tsai, 1978; Lee et al., 1980). The Kueishantao island offshore the Ilan plain is an andesitic volcano (Ho, 1982; Letouzey and Kimura, 1985). It is the last volcanic center toward the southwest along the spreading axis of the Okinawa Trough. The isotopic and chemical compositions of volcanic rocks of the central Okinawa Trough (Iheya and Aguni deeps, hereafter I\&A) have been studied by Ishizuka et al. (1990), Auzende et al. (1990), Honma et al. (1991) and Shinjo (1992). Some chemical analyses and petrographic studies of volcanic rocks on Kueishantao have been reported by Chang and Chen (1979), Chen and Kato (1989) and Chang-Hwa Chen et al. (1990a).

In this paper, we present $\mathrm{Nd} . \mathrm{Sr}$ and $\mathrm{O}$ isotopic and chemical studies of volcanic rocks on Kueishantao and compare these with rocks from the spreading axis of the central Okinawa Trough. We attempt to interpret variations between magmas along the spreading axis in an active back-arc basin in terms of its different evolutionary stages and the relationship between back-arc basin basalt and island-arc basalt.

\section{Samples and analytical procedures}

Seven samples from Kueishantao were collected from four localities (Fig. 1C). Petrographically these 
Table I

Isotopic compositions of volcanic rocks in the Okinawa Trough

\begin{tabular}{lcccc}
\hline & $\delta^{18} \mathrm{O}^{\mathrm{a}}$ & ${ }^{87} \mathrm{Sr} /{ }^{86} \mathrm{Sr}^{\mathrm{b}}$ & $\mathrm{E}_{\mathrm{Nd}}^{\mathrm{c}}$ & LOI (\%) \\
\hline \multicolumn{2}{l}{ Kueishantao } \\
KS-3 & 7.1 & 0.70581 & -2.9 & 0.22 \\
KS-5 & 7.8 & 0.70651 & -4.3 & 0.76 \\
KS-6 & 7.6 & 0.70587 & -1.9 & 0.67 \\
KS-8 & 7.8 & 0.70593 & -2.5 & 0.94 \\
KS-9 & 7.9 & 0.70577 & -2.8 & 0.41 \\
K-A-I & 7.7 & 0.70683 & -4.9 & \\
K-B-7 & 7.6 & 0.70688 & -5.2 & \\
Iheva and Aguni deeps $(\text { I and A })^{\mathrm{d}}$ & & \\
B-1-A & 6.6 & 0.70489 & 2.3 & 0.84 \\
A-6 & 6.3 & 0.70444 & 3.8 & 1.00 \\
A-2-A & 6.0 & 0.70440 & 4.3 & 0.94 \\
A-1-B & 6.2 & 0.70441 & 4.7 & 0.99 \\
12-2 & 7.6 & 0.70434 & 4.4 & 1.33 \\
\hline
\end{tabular}

${ }^{a} \delta^{18} \mathrm{O}=\left[\left({ }^{18} \mathrm{O} /{ }^{16} \mathrm{O}_{\text {sample }} /{ }^{18} \mathrm{O} /{ }^{16} \mathrm{O}_{\text {MORB }}\right)-1\right] * 1000$, SMOW (standard mean ocean water); reproducibility $= \pm 0.2 ;$ NBS-28 $\delta^{18} \mathrm{O}=9.6$.

"Normalized to ${ }^{88} \mathrm{Sr} /{ }^{86} \mathrm{Sr}=0.1194 ;(2 \sigma)$ reproducibility $=0.00004$; NBS987 ${ }^{87} \mathrm{Sr} /{ }^{86} \mathrm{Sr}=0.710226$

Normalized to ${ }^{146} \mathrm{Nd} /{ }^{144} \mathrm{Nd}=0.7219, \quad \epsilon_{\mathrm{Nd}}=\left[\left({ }^{143} \mathrm{Nd} /{ }^{144} \mathrm{Nd}\right) /\right.$ $0.512643] * 10,000 ; \quad(2 \sigma)$ reproducibility $= \pm 0.5 \epsilon_{\mathrm{Nd}} ; \quad \mathrm{UCSD}$ ${ }^{143} \mathrm{Nd} /{ }^{144} \mathrm{Nd}=0.511845$.

${ }^{d}$ Chemical and isotopic data from Honma et al. (1991).

samples can be classified as olivine hornblende andesites and hornblende andesites. $\mathrm{Sr}, \mathrm{Nd}$ and $\mathrm{O}$ isotopic analyses were carried out using conventional chemical and mass spectrometric procedures at Taipei ( $\mathrm{Sr}$ and $\mathrm{Nd})$ and West Lafayette (O), respectively, with negligible blanks (e.g., $0.25 \mathrm{ng} \mathrm{Sr}$ for the extraction of about $20 \mu \mathrm{g} \mathrm{Sr}$ from $100 \mathrm{mg}$ rock). Details for isotopic analyses can be found in Chang-Hwa Chen et al. (1990b). Elemental analyses were measured using XRF, ICP-AES and other conventional techniques. Error estimates and values for the isotopic standards are given in the footnote of Tablc 1 .

\section{Results}

\subsection{Chemical compositions}

All Kueishantao samples analyzed in the present study have low loss on ignition content (LOI $<1 \%$ ) and petrographic examination of thin sections revealed no evidence of alterations. Concentration ranges are $59-61 \%$ for $\mathrm{SiO}_{2}, 3.8-5.2 \%$ for $\mathrm{MgO}, 11-29 \mathrm{ppm}$ for
$\mathrm{Ni}, 74-86 \mathrm{ppm}$ for $\mathrm{Rb}, 221-317 \mathrm{ppm}$ for $\mathrm{Sr}, 18-21$ ppm for La and 2.0-2.6 ppm for Yb (Table 2). Generally speaking, these samples have uniform chemical compositions, although they came from an area of $15 \times 10 \mathrm{~km}$.

\subsection{Isotopic values}

These samples analyzed display $\epsilon_{\mathrm{Nd}}$ from -1.9 to $-5.2 ;{ }^{87} \mathrm{Sr} /{ }^{86} \mathrm{Sr}$ and $\delta^{18} \mathrm{O}$ values of samples show a range from 0.7058 to 0.7069 and 7.1 to 7.9 , respectively (Table 1). They exhibit much lower $\epsilon_{\mathrm{Nd}}$ and higher ${ }^{87} \mathrm{Sr} /{ }^{86} \mathrm{Sr}$ and $\delta^{18} \mathrm{O}$ than those of volcanic rocks from well-known back-arc basins [e.g., the Bransfield Strait lavas, ${ }^{87} \mathrm{Sr} /{ }^{86} \mathrm{Sr}=0.7035-0.7039$, Weaver et al. (1979); the East Scotia Sea, $\epsilon_{\mathrm{Nd}}=9-10$ and ${ }^{87} \mathrm{Sr} /$ ${ }^{86} \mathrm{Sr}=0.7025-0.7035$, Luff (1982), Tarney et al. (1977); the Mariana back-arc basin, $\epsilon_{\mathrm{Nd}}=9.3-11.9$, ${ }^{87} \mathrm{Sr} /{ }^{86} \mathrm{Sr}=0.7027-0.7033$, Woodhead and Fraser

Table 2

Chemical compositions of rocks from Kueishantao

\begin{tabular}{|c|c|c|c|c|c|}
\hline Sample: & KS-3 & KS-5 & $\mathrm{KS}-6$ & KS-8 & KS-9 \\
\hline $\mathrm{SiO}_{2}$ & 59.79 & 61.41 & 60.02 & 59.79 & 59.99 \\
\hline $\mathrm{TiO}_{2}$ & 0.67 & 0.54 & 0.66 & 0.67 & 0.66 \\
\hline $\mathrm{Al}_{2} \mathrm{O}_{3}$ & 16.01 & 14.18 & 16.13 & 16.31 & 16.05 \\
\hline $\mathrm{Fe}_{2} \mathrm{O}_{3}$ & 6.80 & 2.51 & 2.82 & 2.72 & 2.92 \\
\hline $\mathrm{FeO}$ & 1.02 & 4.31 & 4.30 & 4.70 & 4.38 \\
\hline $\mathrm{MnO}$ & 0.12 & 0.11 & 0.12 & 0.12 & 0.12 \\
\hline $\mathrm{MgO}$ & 3.90 & 5.23 & 3.79 & 3.86 & 3.84 \\
\hline $\mathrm{CaO}$ & 6.82 & 6.89 & 6.75 & 6.65 & 6.86 \\
\hline $\mathrm{Na}_{2} \mathrm{O}$ & 2.46 & 2.11 & 2.50 & 2.48 & 2.49 \\
\hline $\mathrm{K}_{2} \mathrm{O}$ & 1.85 & 1.99 & 1.90 & 1.90 & 1.87 \\
\hline $\mathrm{P}_{2} \mathrm{O}_{5}$ & 0.14 & 0.11 & 0.14 & 0.15 & 0.14 \\
\hline LOI & 0.22 & 0.76 & 0.67 & 0.94 & 0.41 \\
\hline Total & 99.80 & 100.15 & 99.80 & 100.29 & 99.73 \\
\hline $\mathbf{R b}$ & 77 & 86 & 78 & 74 & 76 \\
\hline $\mathrm{Sr}$ & 317 & 221 & 311 & 308 & 316 \\
\hline $\mathrm{Ba}$ & 384 & 302 & 371 & 378 & 384 \\
\hline $\mathrm{Y}$ & 20 & 20 & 21 & 24 & 21 \\
\hline $\mathrm{Zr}$ & 148 & 138 & 138 & 142 & 140 \\
\hline V & 154 & 133 & 136 & 162 & 158 \\
\hline $\mathrm{Ni}$ & 12 & 29 & 12 & 13 & 11 \\
\hline $\mathrm{Cr}$ & 47 & 179 & 42 & 54 & 50 \\
\hline $\mathrm{Be}$ & 1.7 & 2.0 & 2.0 & 2.0 & 2.0 \\
\hline Co & 17 & 22 & 20 & 19 & 20 \\
\hline Sc & 19 & 26 & 23 & 22 & 23 \\
\hline $\mathbf{L a}$ & 18 & 22 & 20 & 21 & 20 \\
\hline $\mathrm{Ce}$ & 44 & 50 & 47 & 49 & 47 \\
\hline $\mathrm{Yb}$ & 2.0 & 2.3 & 2.6 & 2.5 & 2.5 \\
\hline
\end{tabular}




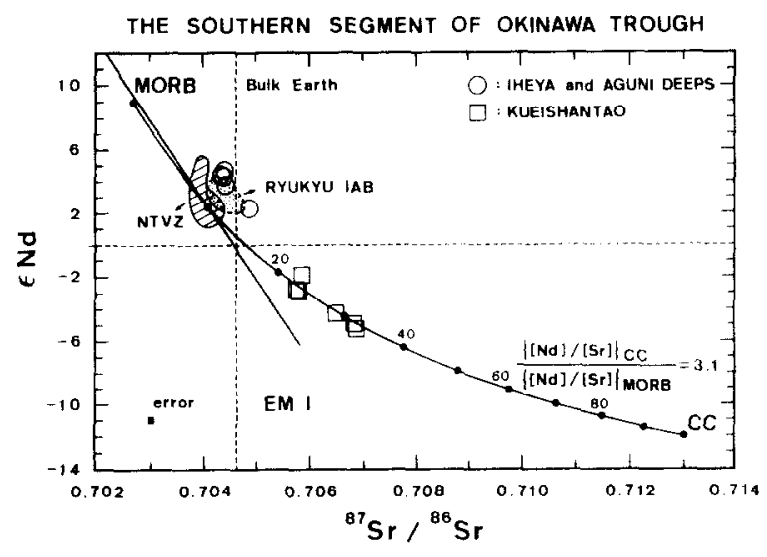

Fig. 2. Neodymiunt vs. strontiun isotope correlation diagram. Data for Kueishantao span a small range and are strongly affected by an enriched component. Mixing of MORB and average local continental crust $(C C)$ can explain the Kueishantao points which lie close to $([\mathrm{Nd}] /[\mathrm{Sr}])_{r_{C}} /([\mathrm{Nd}] /[\mathrm{Sr}])_{\text {MORB }}=3: 1$ curve. The strontium isotopic compositions of the central segment (IA) shift to higher ${ }^{87} \mathrm{Sr} /$ ${ }^{86} \mathrm{~S} r$, possibly as a result of seawater interaction. The shaded area shows the isotopic variations of basaltic rocks in the northern Taiwan Volcanic Zonc (NTVZ, samples from the Tatun volcanic area and offshore volcanic islands of northern Taiwan, Chen, 1989) The dotted area shows the isotopic values of northern Ryukyu Island-arc basalts ( $I A B$, samples from Satsuma-Iwo-jima, Kuchinoerabu-jima and Suwanose-jima, Chen and Nakada, 1994, unpubl. data). Endmember values are listed in Table 3. Tick marks on the solid curve indicate the fraction in percent of the continental crust component.

(1985), Volpe et al. (1987), $\delta^{18} \mathrm{O}=5.8-6.0$, Ito and Stern (1985)].

\section{Interpretation and discussion}

\subsection{The $\mathrm{Nd}-\mathrm{Sr}-\mathrm{O}$ isotopic relations}

A plot of $\epsilon_{\mathrm{Nd}}$ vs. ${ }^{87} \mathrm{Sr} /{ }^{86} \mathrm{Sr}$ for the Okinawa Trough volcanic rocks is shown in Fig. 2. All samples of Kueis hantao reveal extremely lower $\epsilon_{\mathrm{Nd}}$ and higher ${ }^{87} \mathrm{Sr} /{ }^{86} \mathrm{Sr}$ than those of the central Okinawa Trough (I\&A; Honma et al., 1991), the northern Taiwan Volcanic Zone (NTVZ, basaltic rocks from the Tatun area and offshore islands in northern Taiwan; Chen, 1989) and the northern Ryukyu Island Arc basalts (IAB, basaltic rocks from Satsuma-Iwo-jima, Kuchinoerabu-jima and Suwanose-jima; Chen and Nakada, 1994, unpubl. data). Since the distribution of Kueishantao data falls to the right of the mantle array in the fourth quadrant in Fig. 2, it suggests that an enriched component was involved in magma generation. Honma et al. (1991) claimed that $\mathrm{Sr}$ and $\mathrm{Nd}$ isotopic characteristics of basalts of the I\&A area were explained as a two-endmember (MORB-type magma and continental materials) mixing model. If there is the analogous magma generation in the Okinawa Trough, the distribution of Kueishantao data could be explained in terms of local continental crust or sediments mixing during magma generation with a depleted endmember, such as MORB-type magma. Taiwan granitoids and metasediments are the best representatives of local continental crust (CC; (Chen-Hong Chen et al., 1990; Lan et al., 1990), therefore, the average values of above rocks were used for mixing calculation (Fig. 2, solid curve line). With respect to model estimation, it exhibits that Kueishantao magmas have incorporated $24-32 \%$ local continental crust.

$\mathrm{Sr}$ and $\mathrm{Nd}$ isotopic data of the central Okinawa Trough (I\&A) samples (Honma et al., 1991) fall in the second quadrant on the higher ${ }^{87} \mathrm{Sr} /{ }^{86} \mathrm{Sr}$ side of the estimated mixing curve in Fig. 2. The shift to higher $\mathrm{Sr}$ ratios is possible caused by seawater, however, the mixing proportion of the continental component in the magma of the I\&A area is less than $10 \%$.

The $\delta^{18} \mathrm{O}$ values of Kueishantao samples (7.1-7.9) are significantly higher than those of unaltered mantlederived igneous rocks (about 5.7) (Kyser et al., 1982; Taylor and Sheppard, 1986). Since LOI contents of Kueishantao samples are less than $1 \%$ and no secondary alteration minerals were found in rock thin sections, these $\delta^{18} \mathrm{O}$ data should closely represent the original values of magmas. The abnormal oxygen isotopic compositions thus suggest that high $\delta^{18} \mathrm{O}$ materials were involved in processes of magma generation. This substance can be the continental crust or terrigeneous sediments ( $\mathrm{CC}$ ), which have high $\delta^{18} \mathrm{O}$ values. A plot of $\delta^{18} \mathrm{O}$ vs. $\epsilon_{\mathrm{Nd}}$ volcanic rocks of the central segment and southern tip of the Okinawa Trough shows a negative correlation (Fig. 3a). One exceptional sample, No. 122 from the $\mathrm{I} \& \mathrm{~A}$, has higher $\delta^{18} \mathrm{O}$ value (7.6), silica content $(72.37 \%)$ and LOI (1.57\%) (Honma et al., 1991 ). It was probably caused either by crystal fractionation and/or by alteration at low temperature. The negative correlation between $\delta^{18} \mathrm{O}$ and $\epsilon_{\mathrm{Nd}}$ is also consistent with the model used for interpreting the correlation between $\mathrm{Sr}$ and $\mathrm{Nd}$, namely the two-endmember mixing of MORB-type magma and Taiwan local continental crust. As shown in Fig. 3a and b, Kueishantao 

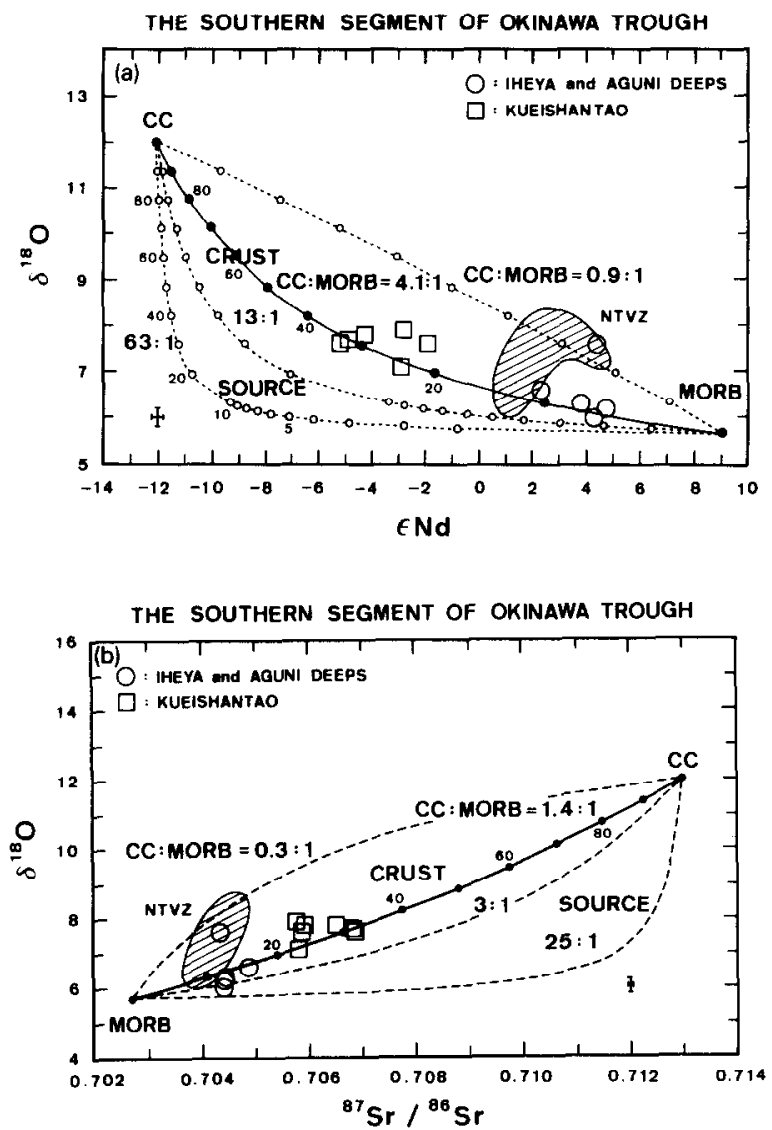

Fig. 3. (a) Neodymium-oxygen isotopic mixing models between continental crust or sediment $(C C)$ and depleted mantle (DM) or MORB-type magma. The dashed lines show the mixing curves according to the assumed Nd concentration ratios of endmembers. The boundary between the crustal contamination and source contamination is the 13:1 curve (see text for details). The shaded area shows the isotopic variations of the basaltic rocks in the northern Taiwan Volcanic Zone (NTVZ) (Chen, 1989). Endmember model compositions are given in Table 3. Tick marks on curves indicate fraction in percent of the continental crust component. (b) Strontium-oxygen isotopic mixing models between continental crust or sediment $(C C)$ and depleted mantle or MORB-type magma. Symbols are the same as in Fig. 3a. The boundary between the crustal contamination and source contamination is the $3: 1$ curve (see text for details).

and the I\&A area magma are estimated to contain 25$35 \%$ and less than $10 \%$ contamination of Taiwan continental crust, respectively. These estimates are in excellent agreement with those obtained from the ${ }^{87} \mathrm{Sr} /$ ${ }^{86} \mathrm{Sr}-\epsilon_{\mathrm{Nd}}$ relationship (Fig. 2).

Petrographic evidence strongly supports the proposition that continental materials have been incorporated into the magma. Xenoliths such as quartzites, diopside- quartz schists, cordierite pyroxene hornfels and sandy pelites are common in Kueishantao andesites (Hsu, 1963).

\subsection{Evidence for crustal contamination}

A large amount of continental materials has been involved in processes of magma generation at Kueishantao as mentioned in above discussion. How and where were the magmas contaminated by the continental materials? As conceivable possibilities for contamination, occurred during magma generation, are considered: continental materials descended with a subducted slab into the mantle wedge contaminated the mantle peridotite (called source contamination); or the mantle-derived magma directly assimilated the continental crust materials when the magma ascends through it (called crustal contamination).

Through the combined use of $\mathrm{O}, \mathrm{Nd}$ and $\mathrm{Sr}$ isotopes, crustal contamination vs. source contamination of a magma can, in principle, be distinguished (James, 1981; Chang-Hwa Chen et al., 1990b). In the case of crustal contamination, the depleted mantle component is the magma in which incompatible elements such as $\mathrm{Sr}$ and $\mathrm{Nd}$ have already been concentrated by partial melting of mantle rocks so that their concentration is comparable to that of the continental crust. Thus, in a plot of $\delta^{18} \mathrm{O}$ vs. Nd or $\mathrm{Sr}$ isotope ratios, the mixing curve between the depleted and the enriched components lies close to the tie line between them (Fig. 3a and b). In contrast, in the case of source contamination, the depleted component is still present in the form of mantle rocks whose concentration of incompatible elements is much lower than that in the enriched component. This disparity causes the mixing curve to be convex downward and to deviate far below the tieline.

It is a notable thing that the oxygen isotope alteration effect and the increasing ${ }^{87} \mathrm{Sr} /{ }^{86} \mathrm{Sr}$ due to interaction with seawater should influence the results, therefore, using $\epsilon_{\mathrm{Nd}}$ with $\delta^{18} \mathrm{O}$ after correction for alteration effects, is essential in any attempt to distinguish source contamination from crust contamination (Chang-Hwa Chen et al., 1990b).

Assuming reasonable ranges for $\mathrm{Sr}, \mathrm{Nd}$ and $\mathrm{O}$ isotope compositions and concentrations for continental crust (Table 3 ), which are plausibly represented by average values for Taiwan granitoids and metasediments (Chen-Hong Chen et al., 1990; Lan et al., 1990), 
Table 3

Characteristics of the endmembers for the magma mixing model

\begin{tabular}{|c|c|c|c|c|c|}
\hline & $\delta^{1 x} \mathrm{O}$ & $|\mathrm{Sr}|$ & ${ }^{87} \mathrm{Sr} /{ }^{86} \mathrm{Sr}$ & $|\mathrm{Nd}|$ & $\epsilon \mathrm{Nd}$ \\
\hline $\begin{array}{l}\text { Continental } \\
\text { crust (Taiwan)" }\end{array}$ & & $5.5-250$ & & $13-50$ & \\
\hline Average (CC) & 12 & 185 & 0.713 & 33 & -12 \\
\hline MORB $^{\mathrm{h}}$ & & $70-200$ & & $4-14$ & \\
\hline $\begin{array}{l}\text { Average } \\
\text { Morb source } \\
(\mathrm{DM})^{c}\end{array}$ & 5.7 & $\begin{array}{l}128 \\
10-17\end{array}$ & 0.7027 & $\begin{array}{l}8 \\
0.8-0.9\end{array}$ & 9 \\
\hline Average & 5.7 & 13.3 & $0.7027^{4}$ & 0.8 & 9 \\
\hline $\begin{array}{l}\mathrm{CC} / \mathrm{DM} \\
\mathrm{CC} / \mathrm{MORB}\end{array}$ & $\begin{array}{l}|\mathrm{Sr}| /|\mathrm{Sr}| \\
3-25 \\
0.3-3.6\end{array}$ & & $\begin{array}{l}|\mathrm{Nd}| /|\mathrm{Nd}| \\
15-63 \\
0.9 \cdot 13\end{array}$ & & \\
\hline
\end{tabular}

'Range and average values for Taiwan sediments from Chen-Hong Chen et al. (1990) and for granitoids from Lan et al. (1990).

'Range data from Cohen and O'Nion (1982) and Sun (1980). Average values from Woodhead et al. (1987) and Zindler and Hart (1986).

"Range data from Chen and Frey (1985) and Sun (1980). Average values from Woodhead et al. (1987) and Zindler and Hart (1986).

we can set the boundary between the two types of contamination for $\mathrm{Nd}$ (in Fig. 3a) at approximately the $[\mathrm{Nd}]_{\mathrm{CC}}:[\mathrm{Nd}]_{\mathrm{MORB}}=13: 1$ curve; the boundary for $\mathrm{Sr}$ (in Fig. 3b) is around a 3:1 curve (see Chang-Hwa Chen et al., 1990b, for details). The data can be fitted by a mixing curve of $\mathrm{CC}: \mathrm{MORB}=4.1: 1$ for $\mathrm{Nd}$ in Fig. $3 \mathrm{a}$ and $\mathrm{CC}: \mathrm{MORB}=1.4: 1$ for $\mathrm{Sr}$ in Fig. 3b. Using the above criteria, we interpret the magma generations of the central and southern tip of the Okinawa Trough as a case of crust contamination. This is not in agreement with the assertion of Honma et al. (1991) that both source and crustal contamination are involved in the magma generation in the central Okinawa Trough (I\&A area). However, at estimation of source contamination, the mantle peridotite should be used as one of the endmembers, not its derived basalt (James, 1981; Chang-Hwa Chen et al., 1990b). The average $[\mathrm{Sr}]$ and [Nd] concentrations of ocean floor basalt ( 171 and 13 ppm, respectively) were mistakenly taken as one of the endmembers in source contamination calculation by Honma et al. (1991), thus as a consequence [ $\mathrm{Sr}]$ and [Nd] concentrations were counted above ten times higher than those calculated by means of usual estimations of the MORB-type mantle ( 13.3 and $0.8 \mathrm{ppm}$, respectively; Zindler and Hart, 1986; Woodhead et al., 1987). The recalculated result shows that the source contamination process of magma generation in the central Okinawa Trough (I\&A basalts) is not clearly identified. This means that the amount of mantle material under the Okinawa Trough, being directly contaminated by the subducted sediments, would be very minor, if calculated by means of the $\mathrm{Nd}-\mathrm{Sr}-\mathrm{O}$ systematic test.

\subsection{Comparison of basaltic rocks from the Okinawa Trough, the Ryukyu Island Arc and the northern Taiwan Volcanic Zone}

The large ion lithophile (LIL) elements and high field strength (HFS) elements ratios (e.g., $\mathrm{Nb} / \mathrm{Zr}$ and $\mathrm{Ba} / \mathrm{Zr}$ ) of back-arc basin basalts could indicate the relationship with the island-arc magma, since the island-arc basalt has a much lower HFS elements content than that of other tectonic settings except N-MORB (Sun, 1980). The $\mathrm{Nb} / \mathrm{Zr}$ and $\mathrm{Ba} / \mathrm{Zr}$ ratios of basaltic rocks from the I\&A, the Ryukyu Island Arc and the NTVZ are shown in Fig. 4. The ratios of I\&A basaltic rocks are distributed off the tie line of MORB and CC and significantly shift to the Ryukyu IAB direction.

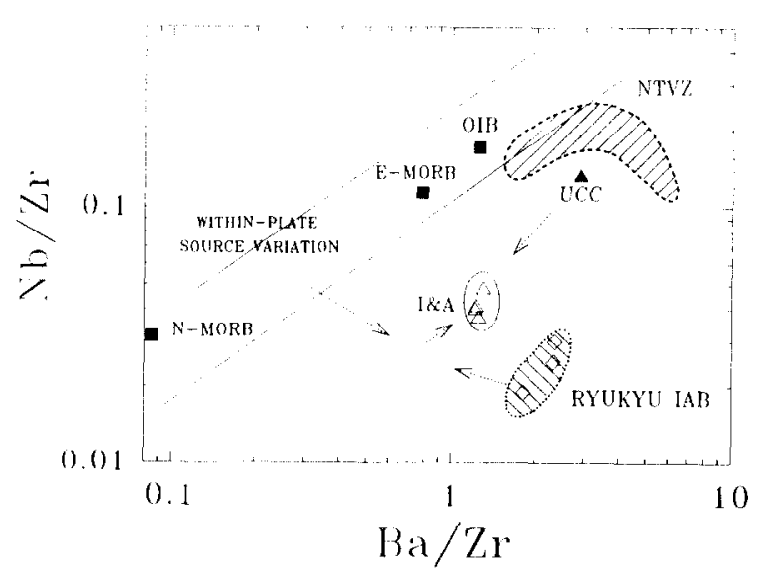

Fig. 4. Plot of $\mathrm{Nb} / \mathrm{Zr}$ vs. Ba/Zr elemental ratios for basaltic rocks of the central Okinawa Trough, the northern Ryukyu Arc and the northern Taiwan Volcanic Zone. I\&A=Iheya Deep and Aguni Deep of the central Okinawa Trough ( Ishizuka et al., 1990); $N T V Z$ = basaltic rocks from the Tatun volcanic area and offshore volcanic islands in northem Taiwan (Chen, 1989; Chen, 1990; Juang, 1993); RYUKYU $I A B=$ basaltic rocks from Satsuma-Iwo-jima, Kuchinoerabu-jima and Suwanose-jima in the northern Ryukyu Island Arc (Chen and Nakada, 1994, unpubl. data). Data sources: $N-M O R B, E-M O R B$ and $O I B$ (ucean island basalt) from Sun and MCDonough (1989); UCC (average upper continental crust) from Taylor and Mclennan (1985). 
This observation suggests that the formation of I\&A magma needs not only two components (MORB-type magma and $\mathrm{CC}$ ) but also an island-arc basalt (IAB) component. The back-arc basin basalt exhibiting both MORB-type and arc-type characteristics is very common in other back-arc basins (e.g., the Mariana Trough, Volpe et al., 1987; the East Scotia Sea, Tarney et al., 1977). The plausible formation of I\&A magma is that the fluid from the dehydrated subduction slab has been added to a magma having the MORB-type trace-element characteristics in the mantle wedge. Afterwards, this magma assimilates with the overlying continental crust, when this magma ascends through it. Unfortunately, no basaltic rocks have been found on Kueishantao, so the trace-element ratio of andesites on Kueishantao can not be used as criterion for distinguishing the island-arc or MORB sources. Anyway, comparison of the isotopic data with those of the Ryukyu Island Arc, indicate that the isotopic values of Kueishantao reveal a really apparent difference (Fig. 2). It implies that except the subduction effect an other major factor has been involved into magma generation.

An unusual volcanic zone in the northern Taiwan Volcanic Zone (NTVZ, Tatun volcanic area and offshore volcanic islands) is located behind the Okinawa Trough. This NTVZ has been considered as a part of the Ryukyu Arc, but it is still debatable because of its special tectonic setting and depth (up to $150-200 \mathrm{~km}$ ) of the Benioff zone under the NTVZ (Yeh et al., 1989).

Comparison of the isotopic values and trace-element ratios of basaltic rocks from the Okinawa Trough with those from the NTVZ (Fig. 3a, b and Fig. 4), reveals that the data distribution of the NTVZ yields much higher $\delta^{18} \mathrm{O}, \mathrm{Nb} / \mathrm{Zr}, \mathrm{Ba} / \mathrm{Zr}$ and little lower $\epsilon_{\mathrm{Nd}}$ and ${ }^{87} \mathrm{Sr} /{ }^{86} \mathrm{Sr}$ values than that of the I\&A area (Chen, 1989; Chen, 1990; Juang, 1993; Chen and Nakada, 1994). The pattern of the NTVZ does not appear to be analogous to the trend of the I\&A and the Ryukyu Island Arc areas. This result suggests that these basaltic rocks of the NTVZ and the Okinawa Trough probably came from different sources. The characteristics of NTVZ basalts are similar to that of northwest Kyushu basalts (Chen and Nakada, 1994); conceivably, as source of the latter basalts, Ocean Island Basalts (OIB)-type magma was considered (Nakada and Kamata, 1991).

\subsection{Tectonic setting and isotopic variations}

The evolution of back-arc basins can be divided into three major stages, namely, "doming", "rifting" and "drifting" (Lee et al., 1980; Letouzey and Kimura, 1985). In the "doming" stage, thermal expansion of the mantle under the crust may cause uplift of the overlying crust. Due to continuous tension by the expansion of mantle, normal faults and small V-shapc valleys appear on the sea floor and some intrusion and extrusion of igneous bodies may thus be emplaced. However, the thickness of the overlying crust is not really reduced until stepping in the "rifting" stage. Finally, at the "drifting" stage, the crust becomes thinner and the new oceanic type crust is formed.

In the Kueishantao area, two seismic refraction profiles across the trough near the Kueishantao area exhibit a narrow and shallow V-shape graben, less than $500 \mathrm{~m}$ in depth and $2 \mathrm{~km}$ in width, cut into the continental shelf (Lee et al., 1980). Topographically, the Kueishantao area is located on a N-S-trending extensional structure and a clear seismic zone exists at depths shallower than $15 \mathrm{~km}$ (Lee, 1983; Yeh et al., 1989). In addition, there is a prominent low-velocity zone right beneath Kueishantao, which may be indicative of magmatic activities (Yeh et al., 1989)

It has becn widely accepted that the Bougucr anomaly values correspond to crustal thickness. The Bouguer anomaly value at Kueishantao is $-13.0 \mathrm{mGal}$ (Yen, 1991, unpubl. data), which is similar to values of the southeastern Eurasian continent shelf at the East China Sea area. This suggests that the continental crust of the Kueishantao area does not show significant thinning. Moreover, inversion of seismic data indicates a crustal thickness of around $30 \mathrm{~km}$ (Vajk, 1964; Yeh et al., 1989), which is similar to the crust thickness of the Eurasian continental shelf crust. Thus, the Kueishantao area is believed to be on the point of entering the "rifting" stage (Fig. 5a). In contrast, the crust at the central Okinawa Trough is about $15 \mathrm{~km}$ thick and displays a wide $(50 \mathrm{~km})$ and deep $(2000 \mathrm{~m})$ graben on the sea bottom (Lee et al., 1980). The Bouguer anomalies of this area also show high values up to $120-140 \mathrm{mGal}$ (Kimura, 1985). It is hence inferred that the original crust has been greatly thinned in the center segment of the Okinawa Trough, probably reflecting the onset of the "drifting"' stage (Fig. 5b). 

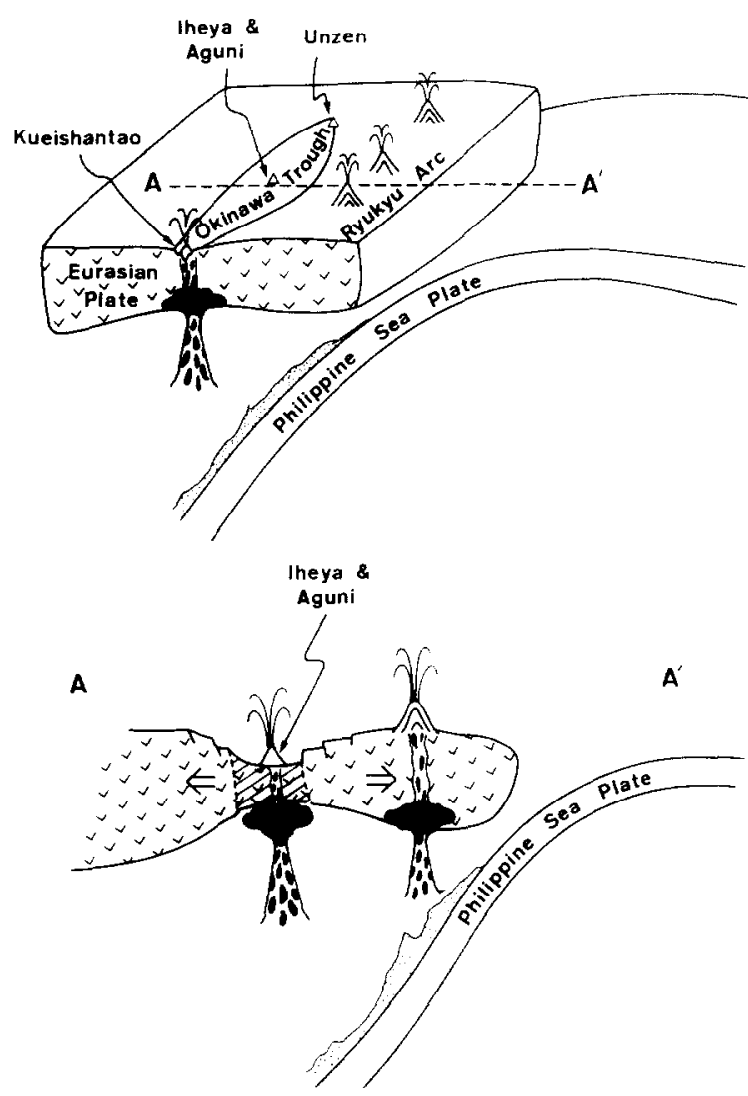

Fig. 5. Cartoon illustrating the geological differences of the volcanoes in the central and tip of the Okinawa Trough. (a) The tectonic setting of Kueishantao and Unzen appears to be at the beginning of the "rifting" stage. (b) In the Aguni and Iheya (I\&A) area, the original crust was thinning as it entered into the "drifting" stage.

Moreover, Kimura (1985, 1990) proposed that the new rifting time of the central segment of the Okinawa Trough started at about $2 \mathrm{Ma}$, but the onset rifting time of southwestern tip of the Okinawa Trough onshore Taiwan is much later. Study of changes in paleo-declination of sediments from Yuanshan Lake in the Ilan Plain, located west of Kueishantao, indicates a clockwise rotation of about $20^{\circ}$ taking place $0.3 \mathrm{Ma}$ after the deposition of the sediments (Fig. 1B; Lee and Liew, 1993).

The isotopic variations of volcanic rocks in the two different parts of the Okinawa Trough can be explained by the above-mentioned structural change. Rocks from the tip segment (i.e., Kueishantao) exhibit high ${ }^{87} \mathrm{Sr} /$ ${ }^{86} \mathrm{Sr}$ and $\delta^{18} \mathrm{O}$ and low $\epsilon_{\mathrm{Nd}}$ values, which can be interpreted as the result of a large amount of assimilation of continental crust during the magma initial ascent when the back-arc basin was just initiated. In contrast, samples from the central segment show high $\epsilon_{\mathrm{Nd}}$ and low ${ }^{87} \mathrm{Sr} /{ }^{86} \mathrm{Sr}$ and $\delta^{18} \mathrm{O}$ values, which implies that magma is relatively free from contamination by continental crust. Nevertheless, the isotopic compositions of the central segment of the Okinawa Trough are different from that of the typical oceanic crust; we believe that oceanic crust is not yet completely formed in the central Okinawa Trough, because of its early development stage in the back-arc basin.

When comparing the structures of central and tip segments of the young back-arc basins, it would appear that the two segments exhibit features characteristic of two different stages. Magma from the tip part exhibits features characteristic of the "rifting" stage, while magma from the central exhibits features of the "drifting" stage. The isotopic variations are also correlated with these stages of back-arc basin spreading.

This hypothesis can be further tested by studying the isotopic variations of Unzen volcano in southwestern Japan, which is located at the northern tip of the Okinawa Trough. The feature of large-scale assimilation of continental crust during the initial magma ascent at the onset of the Unzen graben spreading at about 0.5 Ma (Nakada and Tanaka, 1991) has also been observed (Chen et al., 1991, 1993). However, the temporal isotopic variations in different parts of an actively spreading back-arc basin at the active continental margin await further studies.

\section{Conclusion}

(1) The strong continental signature in Kueishantao volcanic rocks were caused by crustal contamination. It is proposed that MORB-type magma mixed with about $30 \%$ continental crustal matcrials (CC) when the magma passed through the thick continental crust and/or the overlying sediments during the onset of the "rifting"' stage in the active back-arc basin spreading. The degree of crustal assimilation at magma generation in the central segment (I\&A) is much less than that in the tip segment of the back-arc basin.

(2) Based on the trace-element ratios ( $\mathrm{Nb} / \mathrm{Zr}$ vs. $\mathrm{Ba} / \mathrm{Zr})$ of $\mathrm{I} \& \mathrm{~A}$ basaltic rocks, it is suggested that the formation of I\&A magma needs not only two components (MORB-type magma and CC) but also an islandarc basalt (IAB) component. 
(3) Magma of Kueishantao is regarded as the product of the "rifting" stage in the back-arc basin formation, while magma from the central part (I\&A) results from a little more mature back-arc basin segment at the early "drifting"' stage. The isotopic compositions of volcanic rocks provide significant information concerning different stages of back-arc basin evolution.

\section{Acknowledgements}

We thank Dr. J.F. Yu of the Academia Sinica for some of the oxygen analyses. Dr. H.Y. Yen of the Academia Sinica and Prof. J.H. Chen of the Institute of Oceanography, Taiwan University generously provided the samples. Constructive suggestions and comments from Professors M. Flower and S.L. Chung and a anonymous reviewer are gratefully acknowledged. This research was supported by the Academia Sinica and the National Science Council of the Republic of China under grants NSC78-0202-M001-18 and NSC82-0202-M001-103.

\section{References}

Auzende, J.M., Boesptlug, X., Bougault, H., Dossxo, L., Foucher, J.P., Joron, J.L., Ruellan, E. and Sibuet, J.C., 1990. From intracratonic extension to mature spreading in back arc basins: examples from the Okinawa, Lau, North Fiji basins example. Oceanol. Acta, Spec. Vol., 10: 153-163.

Chang, M.D. and Chen, J.C., 1979. Genchemistry of andesites from Kueishantao. Acta Oceanogr. Taiwan., 9: 39-49.

Chen, Chang-Hwa, 1989. Nd-Sr-O isotopic study of Cenozoic arcs volcanic rocks in Taiwan. Ph.D. Thesis, National Taiwan Univ., 198 pp (in Chinese).

Chen, Chang-Hwa and Nakada, S., 1994. Comparison of late Cenozoic basaltic magma generation in Ryukyu Arc, Okinawa Trough and adjoining area (NW Kyushu, Japan and N. Taiwan). 8th Int. Conf. on Geochronology, p. 54.

Chen, Chang-Hwa, Lee, T., Shieh, Y.N. and Chen, C.H., 1990a. Nd$\mathrm{Sr}-\mathrm{O}$ isotopic variations along the spreading axis of Okinawa Trough - a back basin. $1990 \mathrm{Geol}$. Soc. Am Annu. Meet., 22: A25.

Chen, Chang-Hwa, Shieh, Y.N., Lee, T., Chen, C.H. and Mertzman, S.A., 1990b. Nd-Sr-O isolopic evidence for source contamination and unusual mantle component under Luzon Arc. Geochim. Cosmochim. Acta, 54: 2473-2484.

Chen, Chang-Hwa, DePaolo, D.J. and Nakada, S., 1991. Magma generation in back arc basin - the Unzen volcano, northern Okinawa Trough. Geol. Soc. Am., Annu. Meet., 23: A46.
Chen, Chang-Hwa, DePaolo, D.J., Nakada, S. and Shieh, Y.N., 1993. Relationship between eruption volume and neodymium isotopic composition at Unzen volcano. Nature, 362: 831-834.

Chen, Chen-Hong, 1990. The igneous rock of Taiwan. Taiwan Centr. Geol. Surv., 137 pp (in Chinese).

Chen, Chen-Hong, Jahn, B.M., Lee, T., Chen, C.H. and Connichet, J., 1990. Sm-Nd isotopic geochemistry of sediments from Taiwan and complication for the tectonic evolution of SE China. Chem. Geol., 88: 317-332.

Chen, C.Y. and Frey, F.A., 1985. Trace element and isotopic geochemistry of lavas from Haleakala Volcano, east Maui, Hawaii: implications for the origin of Hawaiian basalts. J. Geophys. Res., 90: 8743-8768.

Chen, J.H. and Kato, Y., 1989. Geochemistry of volcanic rocks from the Ryukyu islands: compared with andesitic rocks from northern Taiwan. Acta Oceanogr. Taiwan., 22: 116-128.

Cohen, R.S. and O'Nion, R.K., 1982. The Lead, Neodymium and Strontium isotopic structure of ocean ridge basalts. J. Petrol., 23: 299-324.

Cousens, B.L., Allan, J.F. and Gorton, M.P., 1994. Subduction-modified pelagic sediments as the enriched component in back-arc basalts from the Japan Sea: Ocean Drilling Program Sites 797 and 794. Contrib. Mineral. Petrol., 117: 421-434.

Hawkesworth, C.J., O'Nions, R.K., Pankhurst, R.J., Hamilton, P.J. and Evensen, N.M., 1977. A geochemical study of island arc and back-arc tholeiites from the Scotia Sea. Earth Planet. Sci. Lett., 36: 253-256.

Ho, C.S., 1982. Tectonic evolution of Taiwan explanatory text of the tectonic map of Taiwan. Minist. Econ. Affairs, R.O.C., 126 pp.

Honma, H., Kusakabe, M., Kagami, H., Iizumi, S., Sakai, H., Kodama, Y. and Kimura, M., 1991. Major and trace element chemistry and $\mathrm{D} / \mathrm{H},{ }^{18} \mathrm{O} /{ }^{16} \mathrm{O},{ }^{87} \mathrm{Sr} /{ }^{86} \mathrm{Sr}$ and ${ }^{143} \mathrm{Nd} /{ }^{144} \mathrm{Nd}$ ratios of rocks from the spreading center of the Okinawa Trough, a marginal back-arc basin. Geochem. J., 25: 121-136.

Hsu, L.C., 1963, Petrology of the Pleistocene andesite from Kueishantao, northern Taiwan. Acta Geol. Taiwan., 10: 29-40.

Ishizuka, H., Kawanobe, Y. and Sakai, H., 1990. Petrology and geochemistry of volcanic rocks dredged from the Okinawa Trough, an active back-arc basin. Geochem. J., 24: 75-92.

Ito, E. and Stern, R.J., 1985. Oxygen- and strontium-isotopic investigations of subduction zone volcanism: the case of the Volcano Arc and the Mariana Island Arc. Earth Planet. Sci. Lett., 76: 212320.

Janres, D.E., 1981. The combined use of oxygen and radiogenic isotopes and indications of crustal contamination. Annu. Rev. Earth Planet. Sci., 9: 311-344.

Jenner, G.A., Cawood, P.A., Rautenschlein, M. and White, W.M., 1987. Composition of back-arc basin volcanoes, Valu-Fa ridge: evidence for a slab-drived component in their mantle source. J. Volcanol. Geotherm. Res., 32: 209-222.

Juang, W.S., 1993. Diversity and origin of Quaternary basaltic magma series in northern Taiwan. Bull. Mus. Nat. Sci., 4: 125166.

Kaneoka, I., 1990. Radiometric age and $\mathrm{Sr}$ isotope characteristics of volcanic from the Japan Sea floor. Geochem. J., 24: 7-19.

Karig, D.E., 1971. Origin and development of marginal basins in the western Pacific. J. Geophys. Res., 76: 2542-2561. 
Kimura, M., 1985. Back-arc rifting in the Okinawa Trough. Mar. Pet. Geol., 2: 222-240.

Kimura, M., 1990. Genesis and formation of the Okinawa Trough, Japan. Geol. Soc. Jpn. Mem., 34: 77-88 (in Japanese).

Kyser, T.K.. O'Neil, J.R. and Carmichael, I.S.E., 1982. Genetic relations among basic lavas and ultramafic nodules: evidence from oxygen isotope compositions. Contrib. Mineral. Petrol., 81: 88102.

Lan, C.Y., Lee, T. and Lee Wang, C., 1990. The Rb-Sr isolopic record in Taiwan Gneisses and its tectonic implication. Tectonophysics, 183: 129-143.

Lee, C.S., Shor Jr., G.G., Bibee, L.D., Lu, R.S. and Hilde, T.W.C., 1980. Okinawa Trough: origin of a back-arc basin. Mar. Geol., 35: $219-241$

Lee, T.Q., 1983. Formal mechanism solution and their tectonic implications in Taiwan region. Bull. Inst. Earth Sci., Acad. Sin., 3: $37-54$.

Lee, T.Q. and Liew, P.M., 1993. Preliminary paleomagnetic study on lake sediments at Yuanshan, Ilan, northeastern Taiwan. J. Geol. Soc. China, 36: 419-436.

Letouzey, J and Kimura, M., 1985. Okinawa Trough genesis: structure and evolution of a back arc basin developed in a continent. Mar. Pet. Geol., 2: 111-130.

Luff, I.W., 1982. Petrogenesis of the island arc tholeiite series of the South Sandwich Islands. Ph.D. Thesis, Univ. Leeds, UK.

Nakada, S. and Kamata, H., 1991. Temporal change in chemistry of magma source under central Kyushu, southwest Japan: progressive contamination of mantle wedge. Bull Volcanol., 53: 182194.

Nakada, S. and Tanaka, H., 1991. Magmatic processes of Unzen Volcano. Bull. Volcanol. Soc. Jpn., 36: 113-121

Saunders, A.D. and Tarney, J., 1984. Geochemical characteristics of basaltic volcanism within back-arc basins. In: B.P. Kokelaar and M.F. Howells (Editors), Marginal Basin Geology Volcanic and Associated Sedimentary and Tectonic Process in Modern and Ancient Marginal Basins. Geol. Soc. London, Spec. Publ., 16: $59-76$.

Shinjo, R., 1992. Volcanic rocks from the Okinawa Trough and associated islands, the southern Ryukyu arc, Japan. 29th Int. Geol. Congr., p. 110.

Sun, S.S, 1980. Lead isotopic study of young volcanic rocks from mid-ocean ridge, ocean islands and island arc. Philos. Trans. $R$. Soc. London, Ser. A, 297: 409-445.

Sun, S.S. and McDonough, W.F., 1989. Chemical and isotopic systematics of oceanic basalts: implications for mantle composition and processes. In: A.D. Saunders and M.J. Norry (Editors), Magmatism in the Ocean Basins. Geol. Soc., Spec. Publ., 42: 313-345.
Tarney, J., Saunders, A.D. and Weaver, S.D., 1977. Geochemistry of volcanic rocks from the island arcs and marginal basins of the Scotia Arc region. In: M. Talwani and W.C. Pitman III (Editors), Island Arcs, Deep Sea Trenches, and Back-Arc Basins. Maurice Ewing Ser., 1: 367-377.

Taylor, B. and Karner. G.D., 1983. On the evolution of marginal basins. Rev. Geophys. Space Phys., 21: 1727-1741.

Taylor Jr., H.P. and Sheppard, S.M.F., 1986. Igneous rocks: I Processes of isotopic fraction and isotope systematics. In: J.W. Vallcy, H.P. Taylor Jr. and J.R. O'Neil (Editors), Stable Isotopes in High Temperature Geological Processes. Mineral. Soc. Am., pp. $227-272$.

Taylor, S.R. and Mclennan, S.M., 1985. The Continental Crust: its Composition and Evolution. Blackwell, Oxford, $312 \mathrm{pp}$.

Tsai, Y.B., 1978. Plate subduction and the Plio-Pleistocene orogeny in Taiwan. Pet. Geol. Taiwan, 15: 1-10.

Vajk, R., 1964. Correction of gravity anomalies at sea for submarine topography. J. Geophys. Res., 69: 3837-3844.

Volpe, A.M., MacDougall, J.D. and Hawkins, J.W., 1987. Mariana Trough basalts (MTB): trace clement and $\mathrm{Sr}-\mathrm{Nd}$ isotopic evidence for mixing between MORB-like and arc-like melts. Earth Planet. Sci. Lett., 82: 241-254.

Volpe, A.M., MacDougall, J.D. and Hawkins, J.W., 1988. Lau basin basalts: trace element and $\mathrm{Sr}-\mathrm{Nd}$ isotopic evidence for heterogeneity in back arc basin mantle. Earth Planet. Sci. Lett., 90: 174-186.

Weaver, S.D., Saunders, A.D., Pankhurst, R.J. and Tarney, J., 1979. A geochemical study of magmatism associated with the initial stages of back-arc spreading. Contrib. Mineral. Petrol., 68: 151169.

Wilson, M., 1989. Igneous Petrogenesis. Unwin Hyman, London, $466 \mathrm{pp}$.

Wilson, M. and Davidson, J.P., 1984. The relative roles of crust and upper mantle in the generation of oceanic island arc magmas. Philos. Trans. R. Soc. London, Ser. A, 310: 661-674.

Woodhead, J.D. and Fraser, D.E., 1985, Pb, Sr and Be-10 isotopic studies of volcanic rocks from the northern Mariana Islands: implications for magma genesis and crustal recycling in the western Pacific. Geochim. Cosmochim. Acta, 49: 1925-1930.

Woodhead, J.D., Harmon, R.S. and Fraser, D.G., 1987. O, S, Sr and $\mathrm{Pb}$ isotope variations in volcanic rocks from the northern Mariana islands: implications for crustal recycling in intraoceanic arcs. Earth Planet. Sci. Lett., 83: 39-52.

Yeh. Y.H., Lin, C.H. and Roecker, S.W., 1989. A study of upper crustal structures beneath northeastern Taiwan: possible evidence of the western extension of Okinawa Trough. Proc. Geol. Soc. China, 32: 139-156.

Zindler, A. and Hart, S., 1986. Chemical geodynamics. Annu. Rev. Earth Planet. Sci., 14: 493-571. 